\title{
PERBAIKAN EFISIENSI INTERLEAVED BOOST CONVERTER 200 W PADA KONDISI BEBAN RENDAH MENGGUNAKAN SKEMA PENSAKLARAN ADAPTIF
}

\author{
Riz Rifai Oktavianus Sasue ${ }^{1}$, Eka Firmansyah² ${ }^{2}$ Suharyanto $^{3}$ \\ ${ }^{1}$ Mahasiswa S2 Teknik Elektro / Departemen Teknik Elektro dan Teknologi Informasi, \\ Universitas Gadjah Mada \\ ${ }^{2,3}$ Pengajar/ Departemen Teknik Elektro dan Teknologi Informasi, \\ Universitas Gadjah Mada \\ Email : riz.sie14@mail.ugm.ac.id
}

\begin{abstract}
ABSTRAK
Interleaved boost converter memiliki beberapa keunggulan bila dibandingkan dengan boost converter konvensional diantara lain memperkecil ripple pada sisi masukan dan keluaran, serta transfer energi yang lebih baik. Interleaved boost converter yang beroperasi dalam kondisi daya beban yang rendah (light-load) atau berkisar antara 5 $45 \%$ dari daya beban maksimal akan menyebabkan perubahan mode konduksi kontinyu ke diskontinyu, sehingga efisiensi konverter akan menurun secara signifikan. Makalah ini memaparkan perbaikan efisiensi konverter tipe boost interleaved pada kondisi beban rendah, dengan menerapkan skema pensaklaran adaptif untuk menonaktifkan salah satu fase interleaved dengan maksud menghindari mode konduksi diskontinyu. Setelah menerapkan metode tersebut, diperoleh perbaikan efisiensi sebesar $12,8 \%$ pada saat konverter beroperasi pada beban 5 - $45 \%$ dari desain daya maksimal konverter.
\end{abstract}

Kata Kunci: Intereleaved, Boost Converter, Efisiensi, LTSpice.

\begin{abstract}
Interleaved boost converter has several advantages compared with conventional boost converter such as minimize ripple on input/output and better energy transfer. Interleaved boost converter operating under light-load conditions or at $5-45 \%$ of the maximum power, will altering continuous conduction mode to discontinuous conduction so that the efficiency of the converter will decrease significantly. This paper describes improving the efficiency of interleaved boost converters under light-load conditions by applying adaptive switching scheme to disable one of two interleaved phase in order to avoid discontinuous conduction mode. By applying the method, $12.8 \%$ efficiency improvement is obtained when the converter operates at $5-45 \%$ of maximum power converter design.
\end{abstract}

Keywords: Intereleaved, Boost converter, Effisiency, LTSpice. 


\section{PENDAHULUAN}

Boost converter memiliki peran yang penting untuk menaikan tegangan pada sisi keluaran dari sumber energi listrik, khususnya pada energi terbarukan dimana tegangan yang dihasilkan cenderung rendah dan belum teregulasi. Interleaved boost converter (IBC) merupakan pengembangan topologi boost konverter yang telah populer digunakan dalam konversi energi listrik, beberapa keunggulan dari interleaved boost converter antara lain adalah meminimalisir ripple pada sisi masukan dan keluaran sehingga memperkecil ukuran filter, mereduksi rugi - rugi konduksi pada induktor dan transfer energi yang lebih baik. (Subramanian, Prasanth, Srinivasan, \& Dr.R.Seyezhai, 2015)

Efisiensi pada sebuah konverter berubah - ubah sesuai dengan perubahan kondisi beban. Secara ideal, sebuah konverter seharusnya memiliki tingkat efisiensi yang tinggi untuk seluruh rentang operasinya, ketika interleaved boost convertrer diaplikasikan pada sistem konversi dengan beban yang variatif dan dinamis, dimana konverter harus mengakomodasi beban dengan rentang daya yang lebar yaitu pada kisaran 5 - $100 \%$ daya beban, maka dibutuhkan suatu sistem boost konverter yang memiliki rentang efisiensi yang baik pula, sementara itu interleaved boost converter yang beroperasi pada beban yang relatif rendah antara 5 - $45 \%$ dari daya beban maksimal, nilai arus yang melewati induktor akan menurun karena dampak dari penggandaan jumlah induktor sehingga memaksa konverter bekerja pada mode konduksi diskontinyu (DCM), Saat interleaved boost converter beroperasi pada mode diskontinyu (DCM) rugi - rugi akan meningkat karena meningkatnya peak current pada komponen daya. (Babaa, Armstrong, \& Pickert, 2013).

Pada penelitian ini dilakukan perancangan interleaved boost converter yang dilengkapi rangkaian kontrol dengan skema pensaklaran adaptif. Rangkaian tersebut berfungsi menonaktifkan salah satu induktor pada saat konverter beroperasi pada kondisi daya beban rendah (light-load), untuk menjaga konverter tetap bekerja pada mode konduksi kontinyu (CCM), agar dapat diperoleh suatu 
sistem interleaved boost converter dengan rentang efisiensi yang lebih baik dalam berbagai kondisi pembebanan.

\section{INTERLEAVED BOOST CONVERTER}

Topologi interleaved pada konverter tipe boost dibentuk dengan menggandakan jumlah induktor, saklar elektronis (MOSFET) dan dioda. Boost converter dengan teknik interleaved digerakan oleh saklar elektronis ganda yang dipicu menggunakan pulse width modulation (PWM) dengan beda fasa tertentu dalam setiap periode pensaklaran.

Gambar 1. menunjukan topologi dasar IBC dengan dua fase interleaved $(\mathrm{N}=2)$, dimana terdapat percabangan pada induktor $\mathrm{L}$, yang memisahkan arus masukan I menjadi $\mathrm{I}_{\mathrm{L} 1}$ dan $\mathrm{I}_{\mathrm{L} 2}$. Karena induktor $\mathrm{L}_{1}$ dan $\mathrm{L}_{2}$ bekerja dengan fasa yang berbeda, maka proses pemuatan energi pada induktor L terjadi secara bergantian dan ripple arus terbagi menjadi dua bagian dan memperkecil ripple arus masukan dan tegangan keluaran. (Navamani, Lavanya, Vijayakumar, \& Navauga, 2013; Rahavi, Kanagapriya, \& Seyezhai, 2012; Zhang, Mattavelli, \& Boroyevich, 2012).

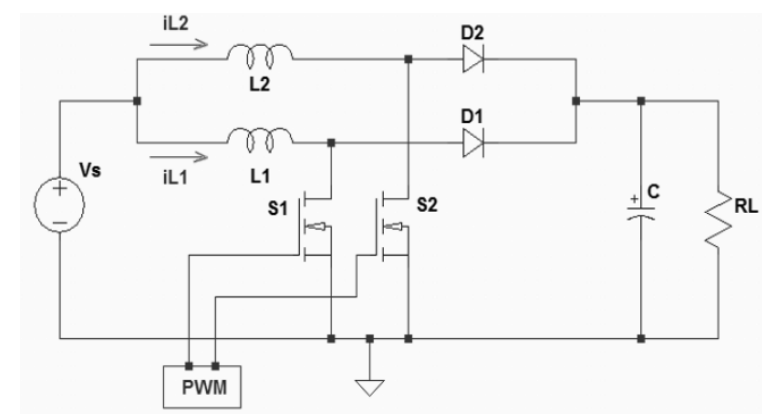

Gambar 1. Rangkaian Dasar Topologi Interleaved Boost Converter

Mengacu pada mode konduksi induktor saat menyalurkan energi ke beban dalam setiap periode pensaklaran, maka boost converter dapat bekerja pada dua mode operasi yang berbeda yaitu, continuous condution mode (CCM) dan discontinuous conduction mode (DCM). (Rashid, 2001; Erickson \& Maksimovic, 2004). 


\section{Continuous Conduction Mode (CCM)}

Pada mode CCM, arus induktor akan selalu lebih besar dari nol dan tidak akan pernah jatuh ke nol dalam setiap periode pensaklaran, sehingga rerata arus induktor akan selalu lebih besar dari separuh nilai puncak ripple arus (Barry et al., 2014). Saat beroperasi pada mode CCM interleaved boost converter bekerja dalam dua tahapan sebagai berikut.

- Tahap 1 , ketika saklar $\mathrm{S}_{1}$ dalam keadaan tertutup, dioda $\mathrm{D}_{1}$ dibias mundur sehingga terjadi pengisian energi pada induktor $\mathrm{L}_{1}$, pada waktu yang bersamaan saklar $\mathrm{S}_{2}$ terbuka, induktor $\mathrm{L}_{2}$ berada dalam kondisi idle dan dioda $\mathrm{D}_{2}$ dibias maju seperti yang ditunjukan pada Gambar 2(a).

- Tahap 2, saklar $S_{1}$ terbuka, dioda $D_{1}$ dibias maju sehingga energi yang tersimpan di dalam induktor $\mathrm{L}_{1}$ akan disalurkan ke beban $\mathrm{R}_{\mathrm{L}}$, dalam waktu yang bersamaan saklar $S_{2}$ tertutup dan dioda $D_{2}$ dibias mundur, sehingga terjadi pengisian energi pada induktor $\mathrm{L}_{2}$ seperti yang ditunjukan pada Gambar 2(b).

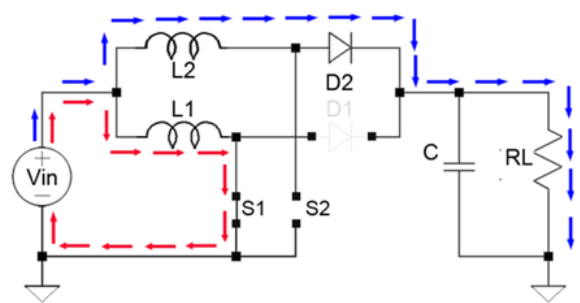

(a)

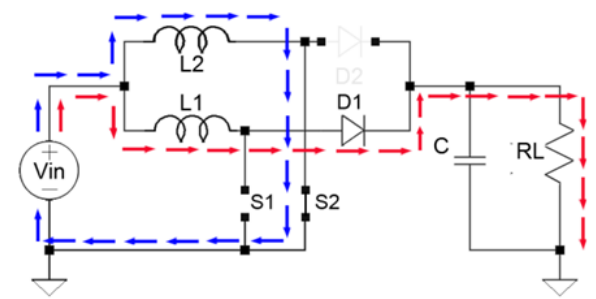

(b)

Gambar 2. Tahapan Kerja Boost Converter : (a) Tahap 1. (b) Tahap 2

Representasi gelombang ideal interleaved boost converter pada mode CCM ditunjukan pada Gambar 3. 


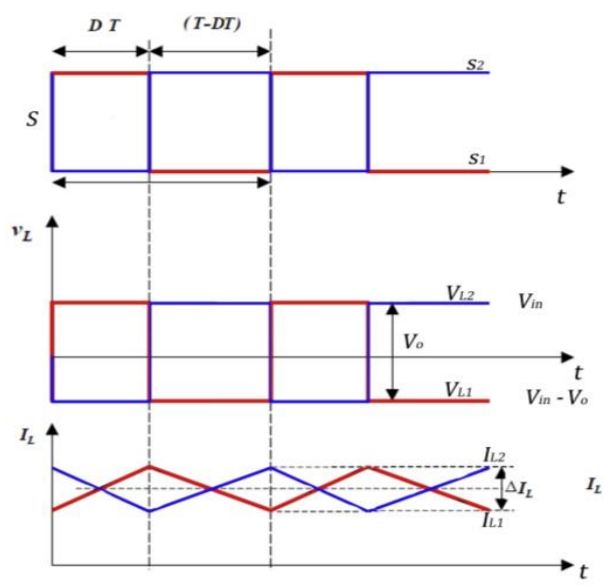

Gambar 3. Gelombang IBC Pada Mode CCM

\section{Discontinuous Conduction Mode (DCM)}

Pada mode DCM arus induktor akan jatuh ke nol ketika dalam kondisi saklar terbuka $\left(\mathrm{t}_{\mathrm{off}}\right)$ pada setiap periode pensaklaran, sehingga terjadi perubahan periode waktu $\Delta \mathrm{t}_{1,2}$ yang menyebabkan energi pada induktor akan habis sebelum satu periode pensaklaran berakhir. Adapun bentuk gelombang interleaved boost converter pada mode DCM ditunjukan pada Gambar 4.

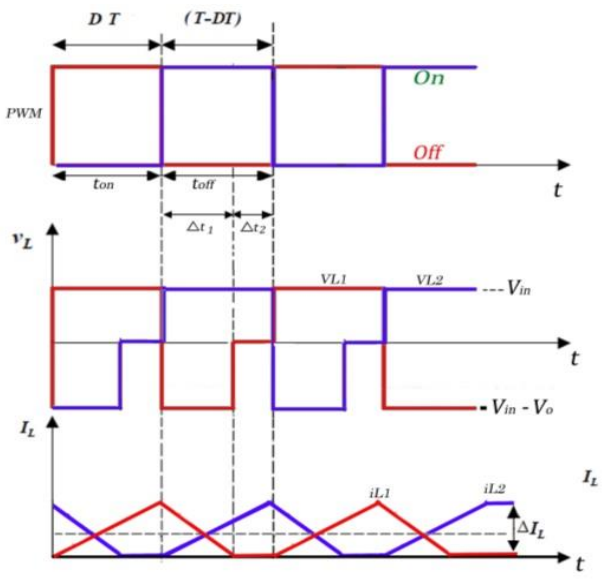

Gambar 4. Gelombang IBC Pada Mode DCM

\section{MODEL DAN PERANCANGAN}

Model dan perancangan dilakukan menggunakan perangkat lunak Ltspice dengan spesifikasi yang ditunjukan pada Tabel 1. 
Tabel 1. Spesifikasi interleaved boost converter

\begin{tabular}{|l|l|}
\hline Parameter & Spesifikasi \\
\hline Daya Keluaran maksimal $\left(\mathrm{Po}_{\max }\right)$ & $200 \mathrm{~W}$ \\
\hline Tegangan Sumber $\left(\mathrm{V}_{\mathrm{in}}\right)$ & $32,48-34,94 \mathrm{~V}_{\mathrm{dc}}$ \\
\hline Tegangan Keluaran $\left(\mathrm{V}_{\mathrm{O}}\right)$ & $120 \mathrm{~V}_{\mathrm{dc}}$ \\
\hline$\%$ Ripple Tegangan keluaran $\left(\Delta \mathrm{V}_{\mathrm{O}}\right)$ & $<1 \%$ \\
\hline Arus Keluaran $\left(\mathrm{I}_{\text {out }}\right)$ & $1,67 \mathrm{~A}$ \\
\hline Frekuensi Pensaklaran $\left(\mathrm{f}_{\mathrm{s}}\right)$ & $100 \mathrm{kHz}$ \\
\hline Duty Cycle Maksimal $\left(\mathrm{D}_{\max }\right)$ & 0,73 \\
\hline IC Kontrol PWM & LT3758 \\
\hline
\end{tabular}

Adapun langkah - langkah perancangan dan penentuan komponen pembentuk konverter dan rangkaian pengendalinya diuraikan sebagai berikut:

\section{Penentuan Induktor}

Untuk menentukan nilai minimum induktor mengacu pada spesifikasi pada Tabel 1, yaitu duty cycle maksimal $\left(\mathrm{D}_{\max }\right) 0,73$, ripple arus induktor $\left(\Delta \mathrm{I}_{\mathrm{L}}\right)$ 1,54 A, tegangan minimal sumber $\left(\mathrm{V}_{\mathrm{in}, \min }\right) 32,48 \mathrm{~V}$ dan frekuensi pensaklaran $\left(\mathrm{f}_{\mathrm{s}}\right) 100 \mathrm{kHz}$. Jika boost konverter membentuk dua fase interleaved $(\mathrm{N}=2)$, maka ukuran minimal induktor $\left(\mathrm{L}_{1,2}\right)$ agar dapat beroperasi pada mode $\mathrm{CCM}$ dapat dihitung dengan menggunakan persamaan berikut:

$$
L_{1,2}=\frac{V_{i n, \min } \cdot D_{\max }}{\Delta \mathrm{I}_{L} \cdot N \cdot f_{s}}=\frac{32,48 \cdot 0,73}{1,54 \cdot 2 \cdot 100000}=76,98 \mu \mathrm{H}
$$

Melalui hasil perhitungan pada Persamaan (1), maka nilai induktansi minimal pada setiap fase interleaved harus sama atau lebih besar dari 76,98 $\mu \mathrm{H}$, dengan demikian induktor yang digunakan pada penelitian ini adalah WE-HCI SMD 74435588200, dengan nilai induktansi $82 \mu \mathrm{H}$, hambatan dalam $\left(D_{R}\right)$ 0,0273 $\Omega$ dan saturasi arus $\left(I_{\text {sat }}\right)$ 8,50 A.

Rugi-rugi yang paling signifikan pada induktor adalah copper loss yang dipengaruhi oleh arus masukan $\left(\mathrm{I}_{\mathrm{in}}\right)$ 6,16 $\mathrm{A}$, hambatan dalam induktor $\left(\mathrm{DC}_{\mathrm{R}}\right)$ $0,0273 \Omega$ dan jumlah fase interleaved $(\mathrm{N}=2)$, sehingga rugi-rugi pada induktor dihitung dengan menggunakan persamaan berikut: 


$$
P_{\text {ind, copper-loss }}=\frac{I_{i n}{ }^{2}}{N}\left(D C_{R 1}+D C_{R 2}\right)=\frac{6,16^{2}}{2}(0,0273+0,0273)=1,04 \mathrm{~W}
$$

\section{Penentuan MOSFET}

Parameter yang perlu diperhatikan dalam penentuan mosfet adalah rugi konduksi, rugi pensaklaran, serta kemampuan operasi arus dan tegangan. (Kavitha, Rajan, \& Vengatesh, 2013). Tegangan operasi maksimum pada MOSFET harus melebihi nominal tegangan keluaran yang diinginkan yaitu $120 \mathrm{~V}$, sedangkan untuk menghitung arus operasi maksimum pada MOSFET mengacu pada nilai duty cycle maksimal ( $\left.\mathrm{D}_{\mathrm{Max}}\right) 0,73$, ripple arus $\left(\Delta \mathrm{I}_{\mathrm{L}}\right) 1,54$ A, arus keluaran ( $\mathrm{I}_{\text {out }}$ ) 1,67 A, sehingga dapat dihitung nilai arus operasi MOSFET ( $\left.\mathrm{I}_{\text {Switch }}\right)$ dengan menggunakan persamaan berikut:

$$
I_{(\text {Switch })}=\frac{\Delta I_{L}}{2}+\frac{I_{\text {out }}}{1-D_{\max }}=\frac{1,54}{2}+\frac{1,67}{1-0,73}=6,96 \mathrm{~A}
$$

Dengan mengacu pada Persamaan (3), serta menambahkan safety margin 25\%, maka pada penelitian ini digunakan N-Chanel MOSFET BSC900N20NS3 dengan spesifikasi tegangan drain-source $\left(\mathrm{V}_{\mathrm{DS}}\right) 200 \mathrm{~V}$, arus drain $\left(\mathrm{I}_{\mathrm{D}}\right) 15$ A dan hambatan drain-source $\left(\mathrm{R}_{\mathrm{DS}(\mathrm{on})}\right)$ 0,009 $\Omega$.

Rugi-rugi pada MOSFET terdiri dari rugi konduksi dan pensaklaran. Rugi konduksi ( $\mathrm{P}_{\mathrm{SW}, \text { cond-loss}}$ ) merupakan disipasi daya pada MOSFET yang terbentuk dari hubungan antara arus masukan $\left(\mathrm{I}_{\mathrm{in}}\right)$ 6,16 A, duty cycle maksimal ( $\mathrm{D}_{\text {Max }}$ ) 0,73 dan hambatan drain-source $\left(\mathrm{R}_{\mathrm{DS}}\right.$ (on) $0,09 \Omega$, sehingga dapat dihitung rugi - rugi konduksi menggunakan persamaan berikut:

$$
P_{S W, \text { cond-loss }}=R_{D S(\text { on })} \cdot D_{\max }\left(I_{\text {in }}\right)^{2}=0,09 \cdot 0,73 \cdot(6,16)^{2}=2,49 \mathrm{~W}
$$

Rugi pensaklaran ( $\mathrm{P}_{\mathrm{SW}, \mathrm{sw}-\mathrm{loss}}$ ) disebabkan oleh perpotongan antara arus drain dan tegangan drain-source dalam setiap periode pensaklaran, sehingga dengan tegangan keluaran $\left(\mathrm{V}_{\text {out }}\right) 120 \mathrm{~V}$, arus masukan $\left(\mathrm{I}_{\text {in }}\right) 6,16 \mathrm{~A}$, turn on time $\left(\mathrm{t}_{\mathrm{on}}\right)$ 9,68 ns, turn-off time $\left(\mathrm{t}_{\mathrm{off}}\right) 4,74 \mathrm{~ns}$, rise-time $\left(\mathrm{t}_{\mathrm{r}}\right) 4 \mathrm{~ns}$, fall-time $\left(\mathrm{t}_{\mathrm{f}}\right) 3$ ns, frekuensi pensaklaran $\left(f_{s}\right) 100 \mathrm{kHz}$, maka dapat dihitung rugi-rugi pensaklaran dengan menggunakan persamaan berikut: 


$$
\begin{aligned}
P_{S W, s w-l o s s}= & \frac{1}{2} \cdot V_{o} \cdot I_{i n}\left(t_{o n}+t_{r}+t_{o f f}+t_{f}\right) \\
= & \frac{1}{2} \cdot 120 \cdot 6,16(9,68+4,75+4+3) \\
& \left(10^{-9}\right) \cdot 100000=0,79 \mathrm{~W}
\end{aligned}
$$

Sehingga melalui Persamaan (4) dan Persamaan (5) dapat diperoleh total rugi - rugi sebesar 3,28 W.

\section{Penentuan Dioda}

Dalam menentukan dioda, parameter utama yang menjadi acuan adalah kecepatan reverse recovery, tegangan reverse harus lebih besar dari tegangan keluaran, begitu juga dengan arus forward harus lebih besar dari arus keluaran. Pada penelitian ini digunakan super fast recovery diode tipe RFN5BM2S dengan spesifikasi arus forward $\left(\mathrm{I}_{\mathrm{F}}\right) 5$ A, arus reverse $\left(\mathrm{I}_{\mathrm{R}}\right) 10$ $\mu \mathrm{A}$, tegangan forward $\left(\mathrm{V}_{\mathrm{F}}\right) 0,9 \mathrm{~V}$, tegangan reverse $\left(\mathrm{V}_{\mathrm{R}}\right) 200 \mathrm{~V}$ dan reverse recovery time $\left(\mathrm{t}_{\mathrm{rr}}\right) 25 \mathrm{~ns}$. Rugi-rugi pada dioda terdiri dari rugi konduksi $\left(\mathrm{P}_{\mathrm{D}, \mathrm{cond}-\mathrm{loss}}\right)$ dan rugi reverse recovery $\left(\mathrm{P}_{\mathrm{D}, \mathrm{rr}-\mathrm{loss}}\right)$. Mengacu pada spesifikasi dioda yang digunakan, dengan arus keluaran $\left(\mathrm{I}_{\text {out }}\right)$ 1,67 A, tegangan keluaran ( $\left.\mathrm{V}_{\text {out }}\right) 120 \mathrm{~V}$ dan duty cycle maksimal (D $\mathrm{D}_{\mathrm{Max}}$ ) 0,73, maka dapat dihitung rugi - rugi pada dioda dengan menggunakan persamaan berikut:

$$
\begin{aligned}
P_{D, \text { cond-losss }} & =N \cdot V_{F} \cdot\left(\frac{I_{\text {out }}}{N}\right)\left(1-D_{\max }\right) \\
& =0,9 \cdot 1,67 \cdot 0,27=0,4 \mathrm{~W} \\
P_{D, r r-l o s s s}= & N \cdot \frac{1}{2} \cdot V_{\text {out }} \cdot\left(\frac{I_{R}}{N}\right) \cdot t_{r r} \cdot f_{s} \\
= & 120\left(\frac{10 \cdot 10^{-6}}{2}\right) 25 \cdot 10^{-9} \cdot 100000 \\
= & 1,5 \mu \mathrm{W}
\end{aligned}
$$

Sehingga melalui (6) dan (7), diperoleh total rugi-rugi pada dioda sebesar $0,4 \mathrm{~W}$.

\section{Penentuan Kapasitor Masukan Dan Kapasitor Keluaran}

Untuk menentukan nilai kapasior keluaran $\left(\mathrm{C}_{\text {out }}\right)$ mengacu pada arus keluaran $\left(\mathrm{I}_{\mathrm{out}}\right)$, ripple tegangan keluaran $\left(\Delta \mathrm{V}_{\mathrm{O}}\right)$, frekuensi pensaklaran $\left(\mathrm{f}_{\mathrm{S}}\right)$, 
sehingga dengan arus keluaran 1,67 A dan ripple tegangan keluaran 0,25\% dari tegangan keluaran atau setara $0,3 \mathrm{~V}$, maka nilai minimum kapasitor keluaran dapat dihitung sebagai berikut:

$$
C_{\text {out }} \geq \frac{I_{\text {out }}}{\Delta V_{o} \cdot 2 \cdot f_{s}} \geq \frac{1,67}{0,3 \cdot 2 \cdot 100000} \geq 27,7 \mu \mathrm{F}
$$

Untuk memperkecil ESR pada $\mathrm{C}_{\text {out }}$ maka pada rangkaian simulasi digunakan dua kapasitor $16 \mu \mathrm{F}$ yang dihubung paralel dengan total kapasitansi $32 \mu \mathrm{F}$, sedangkan kapasitor input $\left(\mathrm{C}_{\text {in }}\right)$ disesuaikan dengan standar operasi kendali PWM LT3758 yaitu $10 \mu \mathrm{F}$. (Linear Technology Corporation, 2009)

\section{Pengaturan Kendali PWM}

Sebagai pengendali PWM digunakan IC LT3758 dengan frekuensi konstan untuk mendapatkan tegangan keluaran yang stabil walau terjadi perubaahan beban. Pada penelitian ini digunakan dua unit pengendali PWM untuk menghasilkan sinyal yang berbeda fasa $180^{\circ}$ antara PWM 1 dan PWM 2, dengan frekuensi konstan $100 \mathrm{kHz}$. Adapun pengaturan yang dilakukan untuk mengoperasikan IC LT3758 diuraikan sebagai berikut:

a. Pengaturan tegangan keluaran

Untuk menetapkan tegangan keluaran pada boost converter dilakukan dengan memberikan tegangan umpan balik 1,6 V sebagai tegangan referensi sesuai standar LT3758. Tegangan umpan balik diperoleh dari resistor $\left(R_{F 1}\right.$ dan $\left.R_{F 2}\right)$ yang membentuk rangkaian pembagi tegangan. Jika tegangan keluaran yang diinginkan $\left(\mathrm{V}_{\text {out }}\right) 120 \mathrm{~V}$ dan nilai hambatan $\mathrm{R}_{\mathrm{F} 2}$ ditentukan sebesar $100 \mathrm{k} \Omega$, maka dapat dihitung nilai hambatan $\mathrm{R}_{\mathrm{F} 1}$ dengan menggunakan persamaan berikut:

$$
R_{F 1}=\left(\frac{V_{\text {out }} \cdot R_{F 2}}{1,6}\right)-R_{F 2}=\left(\frac{120 \cdot 100000}{1,6}\right)-100000=7,4 \mathrm{M} \Omega
$$

b. Penentuan RSENSE

$\mathrm{R}_{\text {SENSE digunakan untuk mensensor arus drain terhadap source yang akan }}$ 
digunakan sebagai arus referensi dalam pengendalian PWM. Penentuan nilai $\mathrm{R}_{\mathrm{SENSE}}$ mengacu pada nilai puncak induktor $\left(\mathrm{I}_{\mathrm{L}, \mathrm{Peak}}\right)$ dan standar tegangan $\mathrm{V}_{\text {SENSE }} 0,08 \mathrm{~V}$, sehingga dengan nilai $\mathrm{I}_{\mathrm{L}, \text { Peak }} 6.94 \mathrm{~A}$, maka nilai RSENSE dapat dihitung seperti berikut:

$$
R_{\text {SENSE }}=\frac{V_{\text {SENSE }}}{I_{L, \text { Peak }}}=\frac{0,08}{6,94}=11,53 \mathrm{~m} \Omega(10)
$$

\section{Perancangan Rangkaian Kontrol Dengan Skema Pensaklaran Adaptif}

Interleaved boost converter pada penelitian ini digerakan oleh dua IC LT3758 untuk menghasilkan dua sinyal PWM yang berbeda fase $180^{\circ}$. Disaat konverter bekerja pada 5\% - 45\% dari daya maksimum, maka salah satu IC kontrol PWM akan dinon-aktifkan dengan cara memberikan tegangan $0 \mathrm{~V}$ ke pin SHDN/UVLO pada IC LT3758 tersebut. Ketika salah satu PWM non-aktif, maka salah satu induktor tidak akan bereaktansi, dan arus dari sisi sumber akan mengalir sepenuhnya melalui satu induktor saja, sehingga mode konduksi diskontinyu (DCM) bisa dihindari. Untuk menjalankan konsep pengendalian tersebut, maka dirancang suatu rangkaian kontrol dengan skema pensaklaran adaptif, yang berfungsi untuk mendeteksi kondisi arus beban dengan mengacu pada karakteristik arus induktor. Melalui konsep pengendalian yang disebutkan diatas maka dapat disusun tabel kebenaran sebagai konfigurasi operasi pensaklaran adaptif yang dapat ditunjukan pada Tabel 2.

Tabel 2. Konfigurasi Operasi Pensaklaran Adaptif

\begin{tabular}{|c|l|c|c|}
\hline $\begin{array}{c}\text { Kondisi Arus } \\
\text { Induktor }\end{array}$ & $\begin{array}{c}\text { Mode } \\
\text { Konduksi }\end{array}$ & $\begin{array}{c}P W M \\
1\end{array}$ & $\begin{array}{c}P W M \\
2\end{array}$ \\
\hline$I_{L}>\left(0,45 \cdot I_{L, \max }\right)$ & CCM & On & On \\
\hline$I_{L}<\left(0,45 \cdot I_{L, \max }\right)$ & DCM & On & Off \\
\hline
\end{tabular}

Output rangkaian kontrol dengan skema pensaklaran adaptif adalah berupa nilai tegangan yang digunakan sebagai pemicu pin SHDN/UVLO pada salah satu unit Kontrol PWM LT3758, nilai tegangan tersebut diperoleh dari 
perbandingan antara arus induktor $\left(\mathrm{I}_{\mathrm{L}}\right)$ dengan nilai $45 \%$ dari arus maksimal induktor $\left(0,45 \mathrm{I}_{\mathrm{L}}\right)$. Variabel arus induktor diperoleh dari hasil sensor arus masukan, sedangkan untuk nilai $45 \%$ arus induktor maksimal diperoleh dari operasi persamaan matematis yang diterapkan ke dalam rangkaian elektronis seperti yang ditunjukan pada Gambar 5.

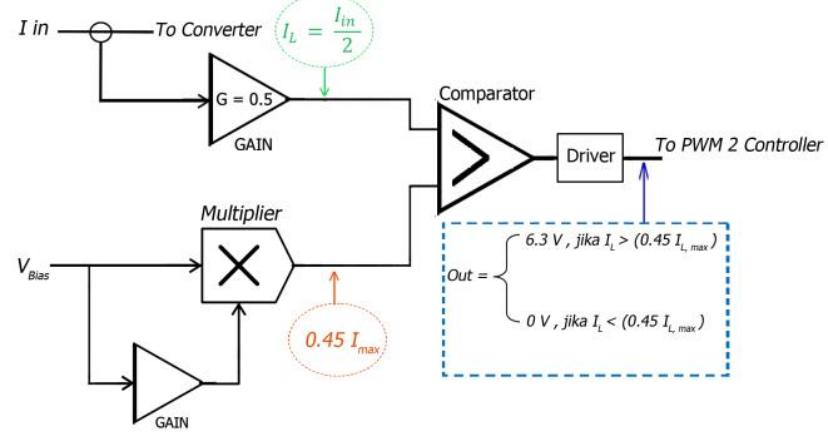

Gambar 5. Diagram Blok Kontrol Pensaklaran Adaptif.

\section{HASIL DAN PEMBAHASAN}

Simulasi dilakukan untuk memverifikasi performa sistem interleaved boost converter yang telah dirancang dalam berbagai kondisi daya pada sisi beban. Sistem disimulasikan dengan menggunakan perangkat lunak Ltspice dengan konfigurasi seperti yang ditunjukan pada Gambar 6.

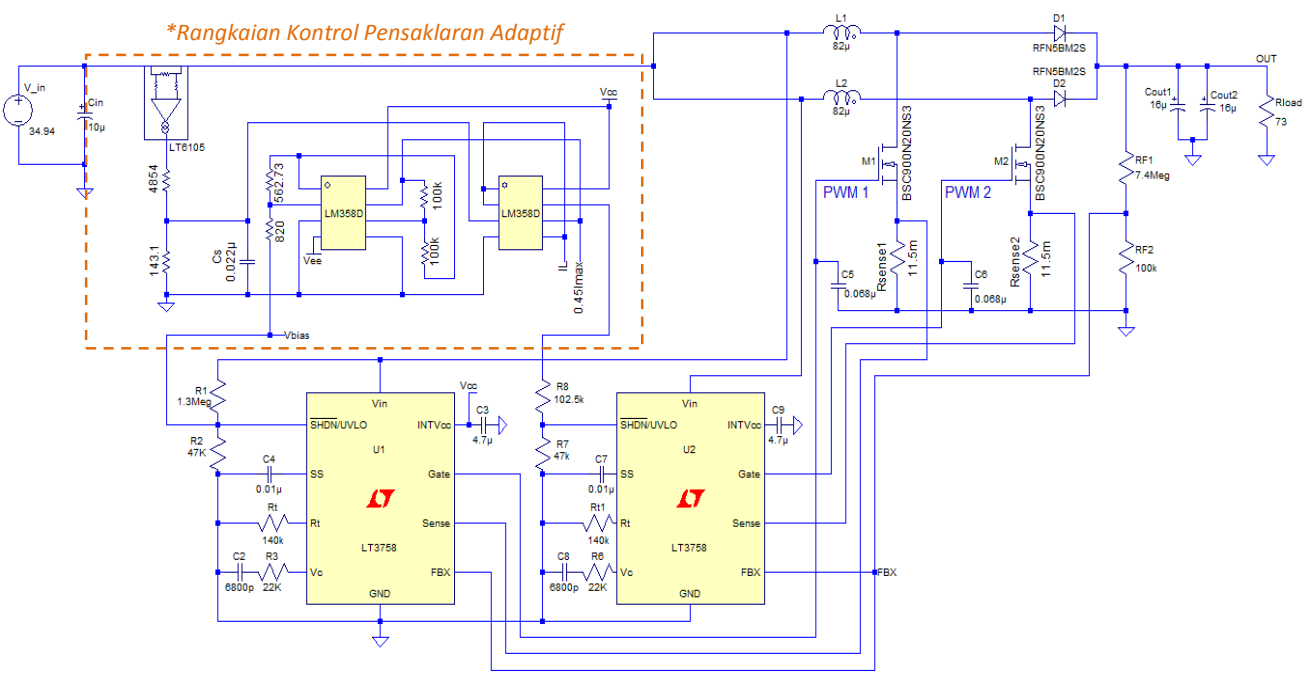

Gambar 6. Rangkaian simulasi pada LTspice 
Hasil pembacaan tegangan pada terminal Op-Amp yang digunakan sebagai komparator untuk mendapatkan tegangan penyulut pin SHDN/UVLO pada kondisi beban penuh (full-load) ditunjukan pada Gbr 7(a). Pada kondisi beban penuh, konverter terdeteksi dalam mode konduksi kontinyu, maka tegangan keluaran Op-Amp bernilai sama dengan tegangan catu senilai $6,3 \mathrm{~V}$ dan mengaktifkan pin SHDN/UVLO pada kedua unit IC LT3758, sehingga PWM 1 dan PWM 2 akan beroperasi. Pada kondisi ini boost converter bekerja secara interleaved dengan bentuk gelombang seperti yang ditunjukan pada Gbr. 7(b) .

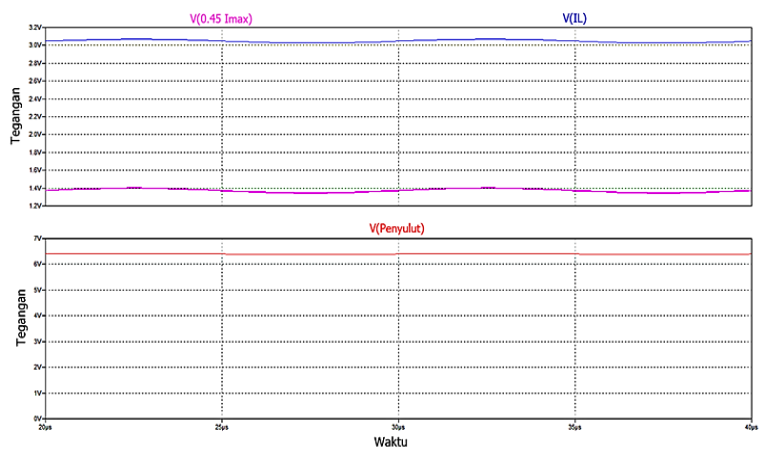

(a)
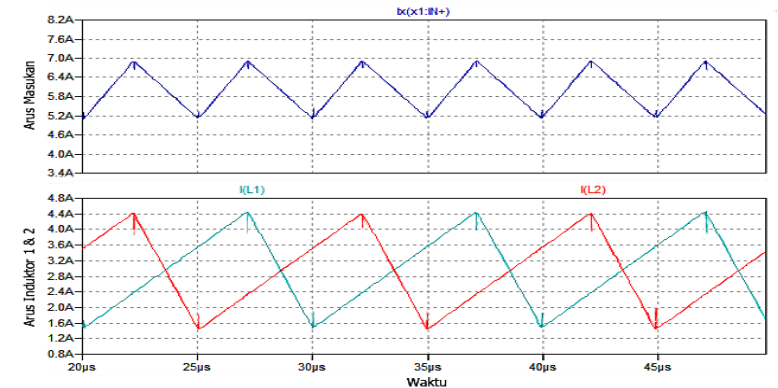

(b)

Gambar 7. Hasil Simulasi Kondisi Beban Penuh : (a) Tegangan Terminal OpAmp. (b) Arus Masukan Dan Arus Induktor $\mathrm{L}_{1}$ dan $\mathrm{L}_{2}$.

Hasil pembacaan nilai tegangan pada terminal Op-Amp sebagai komparator untuk memperoleh tegangan penyulut SHDN/UVLO, pada kondisi beban rendah (light-load) ditunjukan pada Gambar 8(a). Ketika bekerja pada kondisi beban rendah, konverter terdeteksi dalam mode konduksi diskontinyu, sehingga tegangan keluaran Op-Amp bernilai $0 \mathrm{~V}$, dan menyebabkan pin SHDN/UVLO pada LT3758 sebagai kendali PWM 2 akan non-aktif, sehingga induktor $\mathrm{L}_{2}$ tidak 
akan bereaktansi, dengan bentuk gelombang seperti yang ditunjukan pada Gambar 8(b).
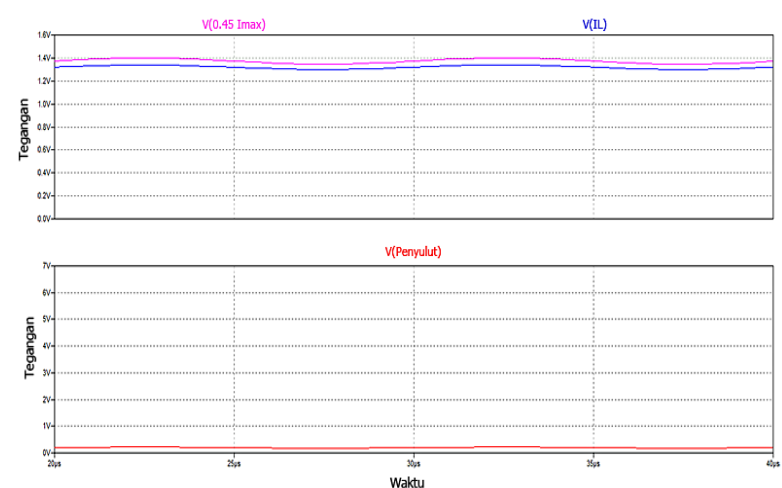

(a)
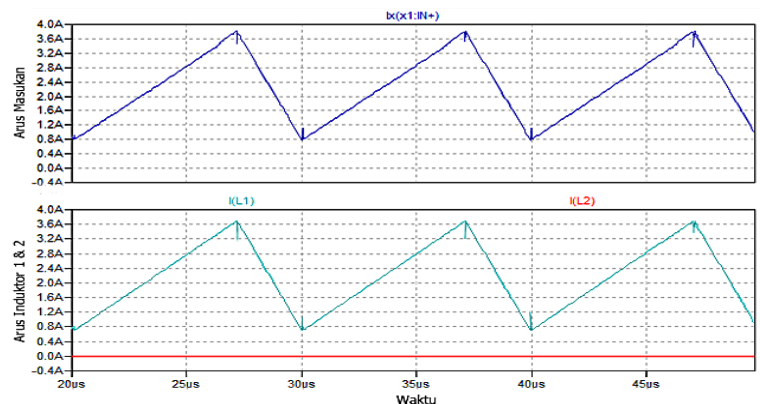

(b)

Gambar 8. Hasil Simulasi Kondisi Beban Rendah : (a) Tegangan Terminal Op-

Amp. (b) Arus Masukan Dan Arus Induktor $\mathrm{L}_{1}$ dan $\mathrm{L}_{2}$.

Gambar 9. menunjukan hasil simulasi tegangan keluaran pada kondisi beban penuh dan beban rendah, dimana nilai tegangan keluaran tetap stabil pada kisaran $120,8 \mathrm{~V}$ walau terjadi perubahan kondis beban, hal ini menunjukan keberhasilan kinerja kedua unit LT3758 sebagai kontrol PWM.

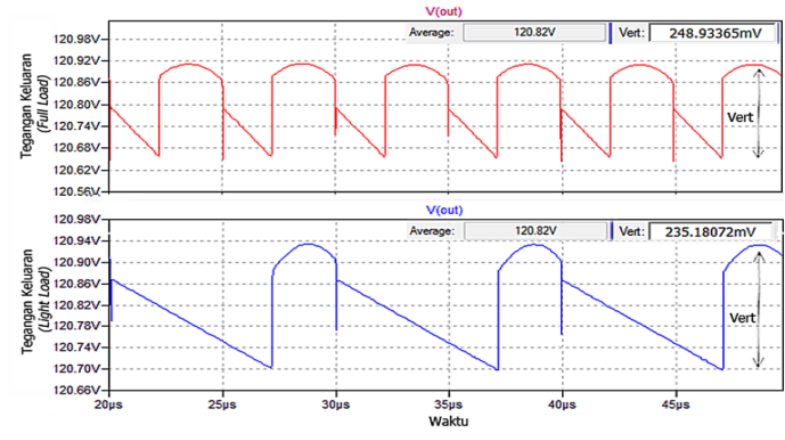

Gambar 9. Hasil Simulasi Tegangan Keluaran. 
Melalui hasil simulasi yang ditunjukan pada Gambar 9, juga diperoleh ripple tegangan dibawah $1 \%$, adapun ripple yang dihasilkan ketika dalam kondisi beban penuh adalah sebesar 248,93 $\mathrm{mV}$ dan pada kondisi beban rendah sebesar 235,18 $\mathrm{mV}$.

Gambar 10. mununjukan kurva efisiensi IBC menggunakan skema pensaklaran adaptif dan tanpa menggunakan skema pensaklaran adaptif (IBC konvensional).

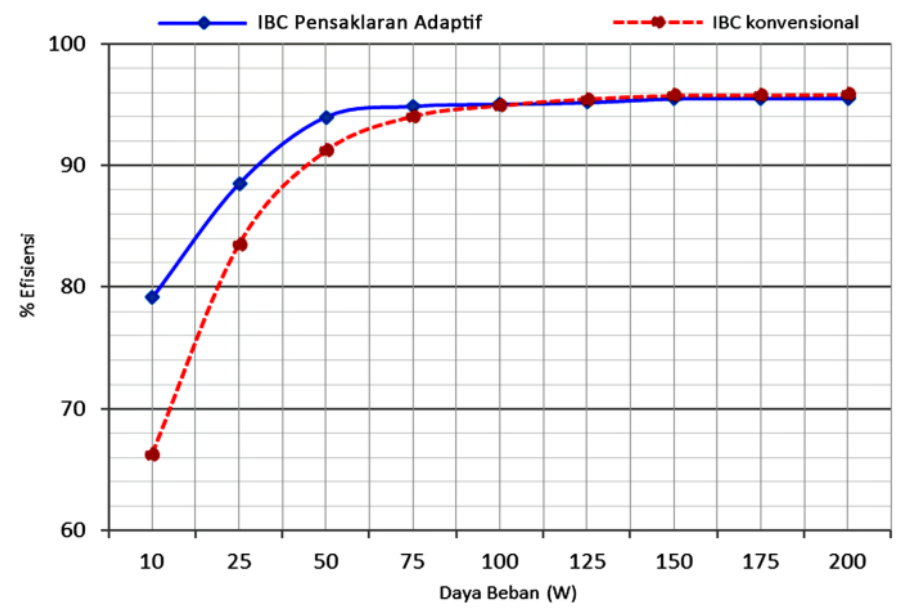

Gambar 10. Efisiensi IBC skema pensaklaran adaptif dan IBC konvensional.

Plot kurva pada Gambar. 10 menunjukan IBC dengan skema pensaklaran adaptif saat beroperasi pada kondisi beban penuh menghasilkan efisiensi 95,64\%, sedangkan IBC konvensional menghasilkan efisiensi sebesar 95,79\%. Sebaliknya ketika beroperasi pada kondisi beban rendah, IBC konvensional menghasilkan efisiensi 66,31\%, sedangkan IBC dengan menggunakan skema pensaklaran adaptif menghasilkan efisensi 79,11\%.

\section{KESIMPULAN}

Perancangan dan simulasi interleaved boost converter $200 \mathrm{~W}$ dengan skema pensaklaran adaptif telah dilakukan dengan menggunakan perangkat lunak LTspice. Hasil simulasi menunjukan tegangan keluaran berada pada kisaran 120,8 $\mathrm{V}$ dengan ripple tegangan dibawah $1 \%$ dalam berbagai kondisi daya beban. Ketika beroperasi pada kondisi daya beban rendah atau 5 - $45 \%$ dari desain daya maksimal konverter (light-load), IBC dengan menggunakan skema pensaklaran 
adaptif berhasil memperbaiki efisiensi IBC konvensional dengan perbaikan sebesar $12,8 \%$, sehingga memungkinkan konverter untuk melayani beban yang dinamis dengan rentang efisiensi yang lebih baik.

\section{DAFTAR PUSTAKA}

Babaa, S., Armstrong, M., \& Pickert, V. (2013). High Efficiency Standalone Photovoltaic System Using Adaptive Switching of an Interleaved Boost Converter. IEEE.

Barry, B. C., Hayes, J. G., Egan, M. G., Rył, M. S., Masłoń, J. W., \& Hartnett, K. J. (2014). CCM and DCM Operation of the Integrated- Magnetic Interleaved Two-phase Boost Converter. IEEE Trans. Ind.Electron., hal 35-42.

Erickson, R. W., \& Maksimovic, D. (2004). Fundamentals of Power Electronics (2nd ed.). Kluwer Academic Publishers.

Kavitha, S., Rajan, S. E., \& Vengatesh, R. P. (2013). Performance Analysis Of Interleaved Dc-Dc Boost Converter For Photo - Voltaicpower Generation Systems. IEEE.

Linear Technology Corporation. (2009). LT3758/LT3758A - High Input Voltage, Boost, Flyback, SEPIC and Inverting Controller, hal 1-36.

Navamani, J. D., Lavanya, A., Vijayakumar, K., \& Navauga. (2013). Comparison Of Efficiencies Of Interleaved Boost Converter For Reenergy Storage System. In International Conference on Green Computing, Communication and Conservation of Energy (ICGCE) (hal. 357-361).

Rahavi, J. S. A., Kanagapriya, T., \& Seyezhai, R. (2012). Design and Analysis of Interleaved Boost Converter for Renewable Energy Source. In International Conference on Computing, Electronics and Electrical Technologies [ICCEET] (hal. 447-451).

Rashid, M. H. (2001). POWER ELECTRONICS HANDBOOK. Academic Press Series in Engineering.

Subramanian, N., Prasanth, P., Srinivasan, R., \& Dr.R.Seyezhai. (2015). Analysis And Experimentation Of Two-Phase Interleaved Boost Converter With Ripple Cancellation Network For Pv Applications. Electrical and Electronics Engineering: An International Journal (ELELIJ), 4(2), hal 105-115.

Zhang, X., Mattavelli, P., \& Boroyevich, D. (2012). Impact of Interleaving on Input Passive Components of Paralleled DC-DC Converters for High Power PV Applications. In 15th International Power Electronics and Motion Control Conference (hal. 1-6). 